\title{
THE PREPARATION OF HIGHLY PURIFIED PR8 INFLUENZA VIRUS FROM INFECTED MOUSE LUNGS*
}

\author{
By C. A. KNIGHT, Ph.D. \\ (From the Department of Animal and Plant Pathology of The Rockefeller Institute for \\ Medical Research, Princeton, New Jersey) \\ Plate 1 \\ (Received for publication, September 20, 1945)
}

The disease agents called viruses appear to be organic substances of such complexity that it is impractical to establish their identity by the classical methods of organic chemistry. However, certain useful methods are available which have been applied very successfully in demonstrating in tobacco mosaic disease that virus activity is a specific property of a high molecular weight nucleoprotein (1). One of the most impressive of these practical approaches is the demonstration, such as was made in the case of tobacco mosaic virus, that virus preparations obtained from widely different hosts possess essentially the same chemical, physical, and biological properties $(1,2)$. Such a comparison has not hitherto been made for a virus affecting animals, largely because sufficiently purified preparations of virus from different animal hosts have not been available. It is particularly important, however, that such an approach be used in the case of animal viruses for it is recognized that the latter are more difficult to purify and hence to identify than are many plant viruses. For instance, while most of the plant viruses appear to be chemically and physically distinct from the materials extractable from normal plants, the isolation of some animal viruses is complicated by the presence of normal materials which are indistinguishable chemically and physically from the infectious material (3-5). It is possible also that animal viruses differ fundamentally from plant viruses in chemical composition, particularly with respect to the lipid component which appears to be consistently a part of every purified animal virus preparation and is regularly lacking among purified plant viruses. If it can be shown that a particular virus contains a certain percentage of lipid when isolated from one host and the same amount in preparations from an entirely different host, the argument that lipid is an integral part of the virus is appreciably strengthened.

Although influenza virus was initially transferred from man to ferrets and then to mice (6) and has,been studied in these animals for a number of years,

\footnotetext{
* The work described in this paper was done under a contract, recommended by the Committee on Medical Research, between the Office of Scientific Research and Development and The Rockefeller Institute for Medical Research. A preliminary report was published in Science, 1945, 101, 231.
} 
highly purified preparations of this virus have been obtained only recently, and these from the allantoic fluid of infected chick embryos $(7,8)$. Such preparations are tremendously active and are composed of uniform particles about $100 \mathrm{~m} \mu$ in diameter which possess distinctive physical, chemical, and biological properties (7-13). The present investigation was undertaken in the hope of obtaining highly purified preparations of influenza virus from infected mouse lungs for comparison with the product isolated from infectious allantoic fluid. It is apparent that infected mouse lungs represent a starting material so different from the allantoic fluid of infected chick embryos that the isolation from each source of a substance possessing common distinctive properties would constitute strong evidence that the substance is the virus.

\section{Methods}

Red Cell Agglutination.-Quantitative red cell agglutination tests were made by the method of Hirst and Pickels (14) asmodified for use in this laboratory (15). A purified virus standard was used throughout; hence the agglutination titers reported herein are on a comparable basis.

Infectivity Titrations.-Titrations in chick embryos and in mice were carried out by previously described methods, using 10 embryos and 10 mice for each dilution tested $(16,17)$.

\section{EXPERTMENTAI}

Inoculation of Mice.-The original inoculum used in this study was a mouse-adapted strain of PR8 infuenza virus kindly provided by Dr. G. K. Hirst. Serial passage of the virus provided additional material for inocula. Four-week-old white mice from the colony of the Department of Animal and Plant Pathology of the Institute were used throughout the investigation.

In an effort to increase the red cell agglutinating titers of the lung tissue extracts, a method of inoculation by spraying was compared with the standard technique of intranasal instillation of droplets under ether anesthesia. Typical results are represented by the following experiment:-

Forty 4-week-old mice were divided into 2 groups of 20 mice. Each mouse in one group was inoculated under ether anesthesia with 2 drops ( $c a .0 .05 \mathrm{ml}$.) of a 1 per cent suspension of infected mouse lung in $0.1 \mathrm{M}$ phosphate buffer at $\mathrm{pH} 7$. The other group was placed in a glass chamber equipped with a loose fitting wire and cardboard top and sprayed with the 1 per cent suspension of infected mouse lung for a period of 5 minutes. ${ }^{1}$ The vaporizer produced an extremely fine and persistent mist some of which was naturally inhaled by the mice as they moved about in the glass chamber. It was operated from a compressed air line and, at a pressure sufficient to produce an appreciable fog, used from 2 to $3 \mathrm{ml}$. of 1 per cent suspension during the 5 minute period of spraying. Groups of 5 mice from each of the 2 lots were sacrificed at 24 hour intervals, with the exception that at the later periods, particularly at 96 hours, there were less than 5 because some animals had died with typical consolidation of the lungs. The lungs were perfused before harvesting, as described below, and were ground in a mortar with sterile sand and enough $0.1 \mathrm{M}$ phosphate buffer at $\mathrm{pH} 7$ to give a 10 per cent suspension on the basis of the wet weight of the lungs. Coarse particles and sand were removed by centrifugation at 5,000 R.P.M. for about 5 minutes. The supernatant fluids

1 The sprayer employed was a Vaponefrin vaporizer produced by the Vaponefrin Company of 6812 Market Street, Upper Darby, Pennsylvania. 
were then tested for ability to agglutinate red cells by the procedure referred to under Methods. The agglutination titers (CCA activities) of the 10 per cent suspensions from the mice inoculated by the standard droplet method were 60,87 , and 43 standard CCA units per ml. at 24,48 , and 72 hours, respectively. Those of the sprayed mice were $<4,76,149$, and 67 CCA units per ml. at $24,48,72$, and 96 hours, respectively.

In general, it was observed that the agglutination titers declined as the lungs became more than 50 per cent consolidated. The titers of the suspensions from completely consolidated lungs were most erratic, for some had appreciable titers and others were inactive. It was apparent from the results of the above and of several other tests that, under the conditions used, the maximum concentrations of extractable virus (as indicated by CCA activity) occurred at approximately 48 hours in the case of the mice inoculated by the standard method and at approximately 72 hours in the case of sprayed mice. More important, the maximum titers of the lung suspensions from sprayed mice were almost invariably about 50 per cent higher than those of the mice inoculated by intranasal instillation of droplets.

Method of Harvesting Lungs.--Influenza virus is adsorbed on red cells of various species (18-21). Moreover both normal and immune sera inhibit the agglutination of red cells by virus (22). Since, as will be described later, adsorption of virus on and agglutination of chicken red cells became a necessary step in the purification procedure, it appeared desirable that as much blood as possible be eliminated from the mouse lungs in order to achieve a maximum agglutination titer. This procedure received justification when the agglutinating titers of suspensions obtained from perfused lungs were compared with those from unperfused lungs. In the perfusion process, the mouse was put under deep ether anesthesia and the thoracic cavity was opened quickly. A 20 gauge needle connected by rubber tubing to an elevated reservoir of saline was inserted in the right ventricle of the heart and an incision was made in the left ventricle. Saline was allowed to flow through the lungs and out of the heart for about 15 seconds. By this time the lungs were white except for areas of consolidation. With the perfusing needle still inserted in the heart, the latter was jerked out by means of forceps with a quick movement which left the lungs behind. The lungs were then extricated with forceps, generally in one cluster, and placed in a Petri dish containing $0.1 \mathrm{M}$ phosphate buffer at $\mathrm{pH} 7$. The buffer, which served to keep the lungs moist and to wash off surface blood, was removed at the end of the harvest by placing the lungs on filter paper on a Büchner funnel and applying gentle suction. The lungs were weighed and then ground and the clarified suspensions in phosphate buffer were tested for CCA activity. In 2 experiments, the 10 per cent suspensions of unperfused lungs titered 50 and $73 \mathrm{CCA}$ units per ml. while corresponding suspensions of perfused lungs gave values of 106 and 117. The titers obtained later from the perfused lungs of groups of 150 to 200 mice were consistently in the neighborhood of $120 \mathrm{CCA}$ units per ml. of 10 per cent suspension. The highest titer observed for a large group of mice was $225 \mathrm{CCA}$ units per $\mathrm{ml}$. or 2,250 units per $\mathrm{gm}$. of wet lung.

Commintion of Lungs.-It is convenient to grind small lots of lungs in a mortar with sterile sand and buffer. With 20 to $40 \mathrm{gm}$. lots this procedure is too laborious; hence tests were made to see whether a Waring blendor might be used. It was found that despite an appreciable amount of foaming in the blendor, the infectivities and CCA activities of the material thus ground were the same as those of the material ground in a mortar. Thereafter, the blendor was employed to release virus particles from lung tissue. The lungs were ground for 2 minutes in 9 times their weight of $0.1 \mathrm{M}$ phosphate bufier at $\mathrm{pH} 7$ and the resulting $10 \mathrm{per}$ cent suspension was spun in an angle centrifuge at 5,000 R.P.M. for 3 to 5 minutes to remove gross particles.

Storage of Virus and Choice of Suspending Medium.-In most cases during the present investigation, it was not possible to work through a sufficiently large number of mice at one time to enable an immediate isolation of virus to be made from the lung material. Therefore 
it was necessary to store 200 to $400 \mathrm{ml}$. lots of 10 per cent suspension until an adequate amount had been accumulated. The experiments of Horsfall indicated that 20 per cent suspensions of infected mouse lungs in infusion broth containing horse serum could be stored at dry ice temperature and frozen and thawed repeatedly without appreciable alteration in the infectious quality of the virus (23). Investigations with PR8 virus from allantoic fluid indicated that $0.1 \mathrm{M}$ phosphate buffer at $\mathrm{pH} 7$ is a good medium in which to preserve the virus at $4^{\circ} \mathrm{C}$. (24) and that it also maintains a constant $\mathrm{CCA}$ activity at $-70^{\circ} \mathrm{C}$. for at least a month (15). Therefore, lung suspensions were made in $0.1 \mathrm{M}$ phosphate buffer at $\mathrm{pH} 7$ as described above and were stored at $-70^{\circ} \mathrm{C}$. for periods up to 1 month. With regard to the storage of purified or partially purified virus, it was found that the CCA activity of a preparation of mouse lung virus partially purified by differential centrifugation remained constant for at least 10 days in $0.1 \mathrm{~m}$ phosphate buffer at $\mathrm{pH} 7$ at $4^{\circ} \mathrm{C}$. On the other hand, more than 50 per cent of the CCA activity was lost in the same period of time when the material was stored in either water or in a composite phosphate-glycine-NaCl buffer (25).

Concentration and Purification of Virus.-Frozen 10 per cent suspensions of infected mouse lung were thawed and pooled. The freezing and thawing process always resulted in the formation of an amount of aggregated insoluble material equivalent to about 15 per cent of the total nitrogen. When this material was removed by low speed centrifugation and suspended in phosphate buffer, it was found to possess on a nitrogen basis only 15 per cent of the CCA activity possessed by the supernatant fluid. It was apparent that the bulk of the aggregated material was non-viral in character and it was found that a substantial amount of the CCA activity associated with it could be recovered by one extraction with $0.1 \mathrm{M}$ phosphate buffer.

Several attempts were made to obtain the virus from clarified, thawed suspensions by centrifugal methods such as had previously been used by other investigators $(26,27)$. However, it was found that such preparations, of which No. 2B in Table I is an example, invariably had low agglutination and infectious titers, possessed a poor solubility in $0.1 \mathrm{M}$ phosphate buffer, were very inhomogeneous in the analytical ultracentrifuge and were manifestly composed to a large extent of non-viral lung material. Therefore, it was necessary to find some other method for purification of the virus.

It was observed that normal lung material, like the normal protein from allantoic fluid (10), was not adsorbed on chicken red cells. It seemed probable, therefore, that much of the inactive material might be left behind if the virus were adsorbed on and subsequently eluted from chicken red cells $(18,19,21,28)$. This proved to be the case and combined with the procedure of differential centrifugation furnished a method for obtaining highly purified virus preparations. The final method will be given in detail at the end of this section. The CCA activities and infectivities of preparations obtained by various procedures are summarized in Table $\mathrm{I}$.

In the course of the study, some differences between the non-viral materials of mouse lungs and of allantoic fluid emerged which have an important bearing on the purification of virus from mouse lungs. The sedimentable protein of normal allantoic fluid is not appreciably affected by freezing and thawing and is readily soluble in $0.1 \mathrm{~m}$ phosphate buffer (10). Since both of these properties are also those of the infectious material, they provide no advantage in the purification of the virus. On the other hand, a substantial amount of the sedimentable non-viral material from mouse lungs is aggregated by freezing and thawing, and both this material and the unaggregated material isolated from normal lungs by differential centrifugation are poorly soluble in $0.1 \mathrm{M}$ 
phosphate buffer. It appears from a comparison of the CCA activity of preparation 3 in Table I with those of some of the other preparations that the freezing and thawing of the mouse lung suspensions, presumably by virtue of eliminating some of the non-viral material, is a valuable aid in separating the virus from the balance of inert material. The CCA activities of 4 other preparations were 5 to 6 times greater than that of preparation 3 and the latter was the only one made from a freshly prepared, unfrozen 10 per cent suspension. It was found possible, however, to increase greatly the CCA

TABLE I

The Activity of Preparations of PR8 Infhenza Virus Obtained from Infected Mouse Lungs

\begin{tabular}{|c|c|c|c|c|}
\hline \multirow{2}{*}{$\begin{array}{l}\text { Prepara- } \\
\text { tion No. }\end{array}$} & \multirow{2}{*}{ Method of preparation } & \multirow{2}{*}{$\begin{array}{l}\text { CCA units per } \\
\text { mg. of nitrogen }\end{array}$} & \multicolumn{2}{|c|}{$\begin{array}{l}50 \text { per cent end-points in grams } \\
\text { of nitrogen* }\end{array}$} \\
\hline & & & Embryos & Mice \\
\hline 1 & $\begin{array}{l}2 \text { adsorptions on and elutions from } \\
\text { red cells and } 2 \text { cycles of differential } \\
\text { centrifugation }\end{array}$ & 28,400 & $10^{-13.1}$ & $10^{-11.0}$ \\
\hline $2 \mathrm{~A}$ & Same as 1 & 24,600 & $10^{-14.3}$ & $10^{-11.0}$ \\
\hline $2 \mathrm{~B}$ & $\begin{array}{l}\text { Same starting material as } 2 \mathrm{~A} . \quad 3 \mathrm{cy}- \\
\text { cles of differential centrifugation }\end{array}$ & 2,080 & $10^{-11.6}$ & $10^{-9.1}$ \\
\hline 3 & Same as $1 \ddagger$ & 5,040 & Not tested & $10^{-11.7}$ \\
\hline 4 & $\begin{array}{l}1 \text { adsorption on and elution from red } \\
\text { cells and } 3 \text { cycles of differential } \\
\text { centrifugation }\end{array}$ & 33,000 & Not tested & Not tested \\
\hline 5 & Same as 4 & 29,800 & $10^{-14.0}$ & $10^{-11.8}$ \\
\hline
\end{tabular}

* Infectivity end-points in the case of the embryo tests and weighted end-points in the mouse tests. In both cases 10 animals were used per test dilution. See references 16 and 17 .

$\ddagger$ Starting material, however, was freshly prepared unfrozen 10 per cent suspension whereas in 1 and in all other cases, the starting material had been stored at $-70^{\circ} \mathrm{C}$. and thawed just before use.

activity of preparation 3 on the basis of the behavior of normal lung material in $0.1 \mathrm{M}$ phosphate buffer.

It was observed that highly purified preparations such as 1 and $2 \mathrm{~A}$ in Table I, were, like comparable preparations from allantoic fluid, readily soluble in $0.1 \mathrm{M}$ phosphate buffer and that very little sediment formed upon storage at $4^{\circ} \mathrm{C}$. for periods up to 1 month. In marked contrast, preparations obtained by differential centrifugation alone and ones obtained from unfrozen suspensions by a combination of methods (see preparations $2 \mathrm{~B}$ and 3 in Table $\mathrm{I}$ ) constantly deposit aggregates upon storage at $4^{\circ} \mathrm{C}$. If these aggregates are removed by centrifugation, the CCA titer of the supernatant fluid rises. For example, when preparation 3 was subjected to this treatment, the CCA activities per $\mathrm{mg}$. of nitrogen of the material remaining suspended in phosphate buffer were 
$5,040,10,500,14,000$ and 18,400 when freshly isolated and after 5, 8, and 16 days, respectively. Such a spectacular increase in CCA activity has not been observed in the case of the less pure preparations obtained by centrifugation alone and the highest titer obtained with these was $3,100 \mathrm{CCA}$ units per mg. of nitrogen. Hence, it appears that the possibility of separating non-viral lung material from infectious material is at least in part dependent upon the ratio of the concentrations of each. This principle was utilized in obtaining preparations 4 and 5. In these instances, one adsorption on and elution from red cells was used to separate the infectious particles from the bulk of the inert lung material. A small amount of the latter is brought along mechanically in this process due to the tendency of the material to aggregate during centrifugal manipulations in $0.1 \mathrm{~m}$ phosphate buffer. This same property, however, makes possible the removal of the inert material from the preparation, for, after 3 cycles of differential centrifugation, the preparation is highly active and shows the physical characteristics of the material obtained by 2 adsorptions on and elutions from red cells.

The complete procedure for the isolation of PR8 virus from infected mouse lungs is given in the following protocol which is exemplary of the combination of methods found to yield the best results. The example used is preparation 5 of Table I.

Four-week-old white mice from the colony of the Institute were sprayed in a glass chamber in lots of 20 for 5 minutes with a 1 per cent clarified suspension of infected mouse lung in $0.1 \mathrm{M}$ phosphate buffer at pH 7. After about 72 hours, when 10 to 20 per cent of the mice had succumbed to the disease, the surviving animals, most of which were moribund, were placed individually under deep ether anesthesia and their lungs were perfused with 0.85 per cent saline and removed and placed in $0.1 \mathrm{~m}$ phosphate buffer at $\mathrm{pH} 7$ at room temperature $\left(20-25^{\circ}\right.$ C.). At the end of the harvest, the buffer was removed by placing the lungs on filter paper on a Büchner funnel and applying gentle suction. The moist lungs were quickly weighed on a rough balance and ground in a Waring blendor for 2 minutes with enough phosphate buffer to give a 10 per cent suspension. The material from the blendor was clarified by spinning for 5 minutes at 5,000 R.P.M. in an angle centrifuge and by pouring the supernatant fluid through glass wool to remove the small amount of fluffy material which did not sediment. The clarified suspension was stored at $-70^{\circ} \mathrm{C}$. in sterile, stoppered Lusteroid tubes until the lungs had been harvested from about 1,200 mice. The accumulated frozen suspensions were liquefied by immersion of the tubes in lukewarm water until the ice was just thawed but the fluid was still cold. The pooled thawed suspension was centrifuged at $4^{\circ}$ at 3,500 R.P.M. for 5 minutes. The pellets obtained by this centrifugation were extracted once with a total of $80 \mathrm{ml}$. of cold buffer and the extract was added to the clarified suspension. To $1,880 \mathrm{ml}$. of cold clarified suspension possessing 116 standard CCA units and $1.2 \mathrm{mg}$. of nitrogen per ml. were added $38 \mathrm{ml}$. of packed chicken red cells (15). After swirling thoroughly, the mixture was allowed to stand at $4^{\circ} \mathrm{C}$. for 2 hours. At this time the agglutinated cells had settled to the bottom of the flask and most of the supernatant fluid, which possessed about $7 \mathrm{CCA}$ units per ml., was removed by decantation. The remaining supernatant fluid was separated from the cells by centrifuging the mixture at 3,500 R.P.M. for 3 minutes and decanting. The cells were then suspended in $150 \mathrm{ml}$. of phosphate buffer and the virus was eluted by incubating 
at $37^{\circ} \mathrm{C}$. for 90 minutes with occasional swirling. The red cells were removed from the mixture by centrifuging at 5,000 R.P.M. for 5 minutes. The virus was recovered from the pink-colored eluate by centrifugation in the quantity centrifuge at 24,000 R.P.M. for 15 minutes. The pellets, which contained the virus, were suspended in $25 \mathrm{ml}$. of phosphate buffer and spun in the angle centrifuge at 5,000 R.P.M. for 5 minutes. The process of alternate highand low-speed centrifugation was repeated 2 additional times to yield about $24 \mathrm{mg}$. of purified material which readily dissolved in $10 \mathrm{ml}$. of $0.1 \mathrm{M}$ phosphate buffer at $\mathrm{pH} 7$ to give a bluishwhite opalescent solution.

\section{Properties of Purified Mouse-Lung Virus}

Biological Properties.-For the sake of comparing infectious qualities; preparations of PR8 virus were twice obtained from allantoic fluid at the same time that preparations of mouse virus were being isolated and under identical conditions. The results were interesting in that they indicated that the purified mouse virus preparations, though containing virus highly adapted to mice, were nevertheless as infectious in embryos as were comparable preparations of egg-adapted virus. The reverse was not true, however, for the purified preparations of mouse virus were about 100 times as infectious for mice as the exactly corresponding preparations of virus from allantoic fluid. ${ }^{2}$ The preparations obtained from allantoic fluid, which corresponded to mouse virus preparations $2 \mathrm{~A}$ and 5 , gave 50 per cent infectivity end-points in chick embryos at $10^{-14.1}$ and $10^{-14.4} \mathrm{gm}$. of nitrogen, respectively, and in mice at $10^{-8.9}$ and $10^{-10} \mathrm{gm}$. of nitrogen, respectively.

As shown in Table I, the highest CCA activity obtained for a purified preparation of PR8 mouse lung virus was about 30,000 CCA units per mg. of nitrogen. On the other hand, purified preparations of PR8 virus obtained from allantoic fluid by comparable techniques always possess CCA activities in the neighborhood of 40,000 units per mg. of nitrogen. The latter titer is not increased by repeated adsorption on and elution from red cells. In order to ascertain whether the significantly lower titer of the mouse lung material was characteristic or was due to residual inert material, one of the preparations was subjected to a third adsorption on and elution from red cells. This process failed to increase the activity of the preparation and therefore indicates that virtually all extraneous inert material removable by this process has been eliminated when such preparations reach a CCA titer of about 30,000 units per mg. of nitrogen.

${ }^{2}$ It should be noted that, although preparations of virus obtained by a combination of the methods of adsorption on and elution from red cells and differential centrifugation possess higher CCA activities than any other preparations obtained in this laboratory, they are often significantly less infectious than the preparations obtained by means of differential centrifugation alone. This is in accordance with the observation of Hirst and of many others that the infectious quality of influenza viruses is much more readily lost than is the red cellagglutinating capacity. In the present instance, the loss of infectivity is likely due at least in part to the step in the procedure in which the virus-red cell mixture is subjected to a temperature of $37^{\circ} \mathrm{C}$. for 1 to 2 hours, although this problem has not been thoroughly studied. 
Sise and Shape.-Sedimentation data were obtained by Mr. H. K. Schachman and Mr. J. Hambleton by means of a Bauer-Pickels type ultracentrifuge $(29,30)$ equipped with a Svensson-Philpot optical system (31, 32). The sedimentation runs were made on preparation 1 of the mouse lung virus and on a preparation of allantoic fluid virus obtained under identical conditions. Both preparations were examined in $0.1 \mathrm{M}$ phosphate buffer at $\mathrm{pH} 7$. The mouse lung preparation was at a concentration of about $3 \mathrm{mg}$. per ml. and that from allantoic fluid at $5 \mathrm{mg}$. per $\mathrm{ml}$. As shown in Figs. 1 and 2, a single boundary was observed in each case. Sedimentation constants of $650 \mathrm{~S}$ and $602 \mathrm{~S}$ were calculated for the purified mouse lung and the purified allantoic fluid preparations, respectively. If the value for the mouse lung preparation is corrected, as described by Lauffer and Stanley (12), for an observed relative viscosity of 1.05, it becomes $685 \mathrm{~S}$.

Electron micrographs of preparation 1 were made through the courtesy of the RCA Laboratories at Princeton with the kind assistance of Dr. James Hillier. An RCA type B electron microscope was used. The material was applied to the collodion mounts at a concentration of $10^{-4} \mathrm{gm}$. per ml. in 0.1 M phosphate buffer, was allowed to dry, and then was washed with a small amount of distilled water and allowed to dry again. Fig. 3 shows a section of a field that was micrographed and enlarged to a total magnification of 13,500 . It can be seen that the particles are circular in shape and measurements indicate that the average diameter is about $100 \mathrm{~m} \mu$.

It is apparent from the electron micrographs as well as from the sedimentation data given above that the size and shape of the particles in highly purified preparations of mouse lung PR8 virus do not differ significantly from those of preparations from allantoic fluid $(10,12)$.

Chemical Tests and Analyses.-Tests and analyses for key substances were made on some of the preparations listed in Table $\mathrm{I}$.

The preparations were essentially freed from phosphate buffer by 2 cycles of centrifugation from distilled water. Most of the moisture was then removed by drying from the frozen state and by further drying the white, fluffy material thus obtained in vacuo over $\mathrm{P}_{2} \mathrm{O}_{5}$ at $60-80^{\circ}$. Many of the analyses were made on aliquots of the solutions obtained by dissolving the dried material in $0.02 \mathrm{~N}$ sodium hydroxide. Nitrogen was determined by the direct nesslerization micro-Kjeldahl method of Koch and McMeekin (33) as modified for use in this laboratory (34), phosphorus by the method of King (35), and carbohydrate by the procedure of Tillmans and Philippi (36). An estimate of the amount of lipid was made on preparation 5 by extraction of the dry material with 3:1 alcohol-ether and after evaporation of the alcohol-ether, by extraction of the fatty residue with petroleum ether. Tests for desoxyribonucleic and ribonucleic acids were made on fat-free material with the Dische and Bial reagents, respectively $(37,38)$.

The averages of the nitrogen and carbohydrate values obtained by analyses on preparations 1,2, and 4 were 10.1 per cent of nitrogen and 6.2 per cent of carbohydrate expressed as glucose. Duplicate phosphorus determinations 
on preparation $2 \mathrm{~A}$ yielded a value of 1.06 per cent of phosphorus. In $10.8 \mathrm{mg}$. of preparation 5 there appeared to be 38 per cent of alcohol-ether-extractable and 33 per cent of petroleum ether-extractable material. Positive color tests for both ribonucleic and desoxyribonucleic acids were obtained.

Analyses were also made on 2 preparations of sedimentable material from perfused normal lungs which were obtained after 3 to 4 cycles of differential centrifugation employing 15 minute periods of high-speed centrifugation. The 2 preparations were found to contain an average of 6.9 per cent of nitrogen, 1.4 per cent of phosphorus, and 3.5 per cent of carbohydrate. The nitrogen and carbohydrate values are definitely lower and the phosphorus somewhat higher than those obtained for the virus preparations.

The analytical values given above and some of the physical properties of the mouse lung materials are compared in Table II with the corresponding properties of normal allantoic protein (10) and of highly purified preparations of PR8 influenza virus obtained from allantoic fluid.

\section{Isoelectric Point. -}

Measurements were made by Miss Mary Lloyd of the electrophoretic mobilities of several preparations of the virus and of the particles obtained by subjecting suspensions of perfused normal lungs to several cycles of differential centrifugation. The Northrop-Kunitz microelectrophoresis cell was employed under the conditions previously used in the study of virus preparations obtained from allantoic fluid (13). The preparations were all examined at a concentration of about $10 \mathrm{mg}$. per $\mathrm{ml}$. Preparations of normal lung material and likewise those of PR8 virus obtained by centrifugation alone, possessed isoelectric points ranging from $\mathrm{pH} 4.1$ to $\mathrm{pH} 4.5$. On the other hand, 2 red cell preparations of the virus ( 1 and 5 ) appeared to be isoelectric at $\mathrm{pH} 5.4$ (39) and 5.35, respectively. In this respect these preparations correspond to concurrent red cell preparations of the virus obtained from allantoic fluid and to other highly purified samples previously studied (13). Three other preparations tested by this method, however, appeared to possess isoelectric points ranging from $\mathrm{pH} 6.75$ to $\mathrm{pH} 7.2$. Also, the curves of mobilities versus $\mathrm{pH}$ of preparations 1 and 5 showed some aberration in the neighborhood of $\mathrm{pH} 7$ while those of the remaining preparations had unusual plateaus between pH 5.5 and 6.8. However, none of the preparations showed a minimum solubility at about $\mathrm{pH} 7$ and, with the exception of preparation 3 and those obtained by centrifugation alone, all appeared to be as soluble in phosphate buffer at $\mathrm{pH} 7$ as the best preparations from allantoic fluid. When the solubility of one of the preparations with an apparent electrophoretic isoelectric point at $\mathrm{pH} 7.05$ was tested in a series of buffers, it behaved like a highly purified virus preparation from allantoic fluid in that it showed a minimum solubility in the neighborhood of $\mathrm{pH} 5$ but differed slightly from the latter in that it was somewhat less soluble in the vicinity of $\mathrm{pH} 6$.

The foregoing data may be summarized with the following conclusions. Mouse lung PR8 virus obtained by centrifugation alone has an isoelectric point near that of normal lung material. Combined with other observations, this indicates that such preparations contain a large proportion of non-viral material. Preparations of virus obtained by a combination of the methods of adsorption on and elution from red cells and centrifugation appear to possess two electrochemical natures, one of which tends toward an electrophoretic isoelectric 
point at $\mathrm{pH} 5.4$ and the other of which exerts an isoelectric influence in the region of $\mathrm{pH} 7$. The former agrees with the solubility behavior of the material and coincides with the electrochemical behavior of the best preparations of

TABLE II

Some Chemical and Physical Properties of Highly Purified Preparations of PR8 Influenza Virus and of Related Materials*

\begin{tabular}{|c|c|c|c|c|}
\hline & $\begin{array}{l}\text { Mouse lung } \\
\text { PR8 virus }\end{array}$ & $\begin{array}{l}\text { Allantoic fluid } \\
\text { PR8 virus }\end{array}$ & $\begin{array}{l}\text { Normal allan- } \\
\text { toic protein }\end{array}$ & $\begin{array}{l}\text { Normal mouse } \\
\text { lung particles }\end{array}$ \\
\hline Nitrogen, per cent......... & 10.1 & 10.2 & 9.0 & 6.9 \\
\hline Phosphorus, per cent...$\ldots \ldots \ldots$ & 1.06 & 0.92 & 0.81 & 1.4 \\
\hline $\begin{array}{c}\text { Carbohydrate (as glucose), per } \\
\text { cent.... } \quad . \quad \ldots \quad \ldots \ldots \ldots \\
\text { Alcohol-ether-extractable, per }\end{array}$ & 6.2 & 6.5 & 7.7 & 3.5 \\
\hline 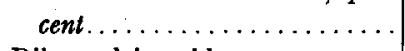 & $38 \ddagger$ & 26.8 & 22.4 & \\
\hline Ribonucleic acid.. & Present & Present & Present & Present \\
\hline $\begin{array}{l}\text { Desoxyribonucleic acid........ } \\
\text { Sedimentation constant ....... }\end{array}$ & $\begin{array}{c}\text { Present } \\
c a .700 \mathrm{~S}\end{array}$ & $\begin{array}{l}\text { Present } \\
\text { ca. } 700 \mathrm{~S}\end{array}$ & $\begin{array}{c}\text { Present } \\
c a .170 \mathrm{~S}\end{array}$ & $\begin{array}{l}\text { Inconclusive } \\
\text { Inhomogeneous }\end{array}$ \\
\hline $\begin{array}{l}\text { Diameter of particles (from elec- } \\
\text { tron micrographs), } m \mu \ldots \ldots \ldots \\
\text { Isoelectric point, } p H \ldots \ldots \ldots \ldots\end{array}$ & $\begin{array}{r}c a .100 \\
5.4\end{array}$ & $\begin{array}{r}\text { ca. } 100 \\
5.4\end{array}$ & $\begin{aligned} & c a . 40 \\
& 2.3\end{aligned}$ & $\begin{array}{l}>40 \\
\text { ca. } 4.2\end{array}$ \\
\hline
\end{tabular}

* The data given for the mouse lung materials are those described in the text of the present report. The nitrogen, phosphorus, and carbohydrate values for PR8 virus obtained from allantoic fluid represent the average from duplicate analyses on 3 lots of virus. One of these lots was a pool of dried material from many preparations totaling over $2,400 \mathrm{mg}$. All of the preparations in this lot and the preparation in another lot were obtained by a procedure of adsorption of the virus on and elution from chicken red cells similar to that used in the preparation of the mouse virus and described in the text. The third lot was the homogeneous material obtained by centrifugal fractionation of partially purified virus (13). The values for the normal allantoic protein are the average of the values obtained with 5 different preparations procured by previously described methods $(10)$. With the exception of the alcoholether-extractable figures, the differences between the analytical values presented for the virus derived from allantoic fluid and for the virus obtained from mouse lungs are no greater than those observed among individual preparations of virus from the same source. It should also be noted that the nitrogen and phosphorus values for the allantoic fluid virus agree well with those reported from another laboratory (9).

$\ddagger$ An approximate value since the single sample analyzed was too small for an accurate analysis.

allantoic fluid virus. The latter, however, appears to be characteristic of the mouse lung virus in that its influence was observed in all preparations thus far examined including one which had thrice been adsorbed on and eluted from red cells.

Serological Tests.-No serum has been prepared as yet against the highly 
purified preparations of mouse lung virus. However, quantitative precipitin tests were made with other available sera with results which will be summarized here and described in detail elsewhere. Purified preparations of the mouse PR8 virus reacted strongly with antiserum to purified PR8 virus obtained from infectious allantoic fluid. Also this serum had a 50 per cent agglutination inhibition end-point of about 40,000 against 8 units of the mouse PR8 virus. The purified mouse PR8 virus failed to precipitate with antiserum to the sedimentable protein of normal allantoic fluid but did precipitate with antiserum to normal lung particles.

\section{DISCUSSION}

The most thorough comparison of virus preparations obtained from two different hosts was made by Loring and Stanley on tobacco mosaic virus isolated from tobacco and from tomato plants (2). In this instance, the proteins isolated from the two hosts were found to have the same chemical, physical, and biological properties. Much the same result has been obtained in the present study on influenza virus. The purified virus preparations isolated from mouse lungs and from allantoic fluid by identical procedures have been found to contain particles of the same size and shape, the same infectivity for chick embryos, essentially the same chemical composition, isoelectric point, and solubility, and common serological properties. Minor but characteristic differences have been observed in electrophoretic behavior and in precipitin tests with antisera to normal tissue particles. Also the lipid content of the mouse PR8 appears to be somewhat higher than that of the allantoic fluid virus although only one isolation of lipid was made and that, of necessity, from a rather small sample. In general, however, it is apparent that the properties of the virus preparations from mouse lungs and from allantoic fluid are remarkably similar and from this fact it can be concluded that the material in each instance probably represents influenza virus.

The author is indebted to Dr. W. M. Stanley for helpful suggestions during the course of this investigation and he was assisted by Mrs. Elmer Greey and Miss Mary Lloyd in perfusing and harvesting the lungs from the several thousand mice employed in the experiments.

\section{SUMMARY}

Highly purified preparations of PR8 influenza virus were obtained from perfused, infected mouse lungs by a combination of methods involving adsorption of the virus on and elution from chicken red cells and differential centrifugation. Such preparations were found to possess 50 per cent infectivity end-points at $10^{-11}$ to $10^{-11.8}$, and $10^{-13}$ to $10^{-14.8} \mathrm{gm}$. of nitrogen in mice and in chick embryos, respectively. A sedimentation constant of $683 \mathrm{~S}$ was obtained for the material and electron micrographs revealed essentially spherical particles about $100 \mathrm{~m} \mu$ in diameter. The material was isoelectric at $\mathrm{pH} 5.4$ 
and chemical analyses on several of the preparations indicated the presence of 10.1 per cent of nitrogen, 1.06 per cent of phosphorus, 6.2 per cent of carbohydrate and about 33 per cent of lipid. Positive tests were obtained for both ribonucleic and desoxyribonucleic acids. The virus was precipitated strongly by antiserum to purified PR8 virus obtained from the allantoic fluid of infected chick embryos and this serum inhibited the agglutination of red cells by the mouse virus to a dilution of about 40,000 .

In general, the properties of the virus isolated from infected mouse lungs were found to coincide with those of the virus obtained from the allantoic fluid of infected chick embryos.

\section{BIBLIOGRAPHY}

1. Stanley, W. M., in Handbuch der Virusforschung, (R. Doerr, and C. Hallauer, editors), Erste Hälfte, Vienna, Julius Springer, 1938, 1, 447.

2. Loring, H. S., and Stanley, W. M., J. Biol. Chem., 1937, 117, 733.

3. Stanley, W. M., in Annual review of biochemistry, (J. M. Luck, editor), Stanford University, Annual Reviews, Inc., 1940, 9, 545.

4. Hoagland, C. L., in Annual review of biochemistry, (J. M. Luck and J. H. C. Smith, editors), Stanford University, Annual Reviews, Inc., 1943, 12, 615.

5. Kabat, E. A., J. Immunol., 1943, 47, 513.

6. Andrewes, C. H., Laidlaw, P. P., and Smith, W., Lancet, 1934, 2, 859.

7. Taylor, A. R., Sharp, D. G., Beard, D., Beard, J. W., Dingle, J. H., and Feller, A. E., J. Immunal., 1943, 47, 261.

8. Stanley, W. M., J. Exp. Med., 1944, 79, 255.

9. Taylor, A. R., J. Biol. Chem., 1944, 153, 675.

10. Knight, C. A., J. Exp. Med., 1944, 80, 83.

11. Lauffer, M. A., and Miller, G. L., J. Exp. Med., 1944, 80, 521.

12. Lauffer, M. A., and Stanley, W. M., J. Exp. Med., 1944, 80, 531.

13. Miller, G. L., Lauffer, M. A., and Stanley, W. M., J. Exp. Med., 1944, 80, 549.

14. Hirst, G. K., and Pickels, E. G., J. Immunol., 1942, 45, 273.

15. Miller, G. L., and Stanley, W. M., J. Exp. Med., 1944, 79, 185.

16. Lauffer, M. A., and Miller, G. L., J. Exp. Med., 1944, 79, 197.

17. Knight, C. A., J. Exp. Med., 1944, 79, 487.

18. Hirst, G. K., Science, 1941, 94, 22.

19. McClelland, L., and Hare, R., Canad. Pub. Health J., 1941, 32, 530.

20. Clark, E., and Nagler, F. P. O., Australian J. Exp. Biol. and Med. Sc., 1943, 21, 103.

21. Francis, T., Jr., and Salk, J. E., Science, 1942, 96, 499.

22. Hirst, G. K., J. Exp. Med., 1942, 75, 49.

23. Horsfall, F. L., Jr., J. Exp. Med., 1939, 70, 209.

24. Knight, C. A., J. Exp. Med., 1944, 79, 285.

25. Miller, G. L., J, Exp. Med., 1944, 80, 507.

26. Hoyle, L., and Fairbrother, R. W., J. Hyg., Cambridge, Eng., 1937, 37, 512.

27. Chambers, L. A., and Henle, W., J. Exp. Med., 1943, 77, 251.

28. Hirst, G. K., J. Exp. Med., 1942, 76, 195. 
29. Bauer, J. H., and Pickels, E. G., J. Exp. Med., 1937, 65, 565.

30. Pickels, E. G., Rev. Scient. Instr., 1938, 9, 358.

31. Svensson, H., Kolloid-Z., 1939, 87, 181.

32. Philpot, J. St. L., Nature, 1938, 141, 283.

33. Koch, F. C., and McMeekin, T. L., J. Am. Chem. Soc., 1924, 46, 2066.

34. Miller, G. L., J. Exp. Med., 1944, 79, 173.

35. King, E. J., Biochem. J., 1932, 26, 292.

36. Tillmans, J., and Philippi, K., Biochem. Z., 1929, 215, 36.

37. Dische, A., Mikrochemie, 1930, 8, 4.

38. McRary, W. L., and Slattery, M. C., Arch. Biochem., 1945, 6, 151.

39. Knight, C. A., Science, 1945, 101, 231. 
EXPLANATION OF PLATE 1

FrG. 1. A photograph of the Svensson schlieren diagram obtained during sedimentation of purified mouse lung PR8 influenza virus, preparation 1. Sedimentation was in $0.1 \mathrm{M}$ phosphate buffer at $\mathrm{pH} 7$ at 11,100 R.P.M. and at a concentration of about 3 mg. per ml. The photograph is the fourth in a series taken at 5 minute intervals.

FIg. 2. The same as Fig. 1 except that the preparation was purified allantoic fluid virus at a concentration of $5 \mathrm{mg}$. per $\mathrm{ml}$.

FIG. 3. An electron micrograph of a purified preparation of PR8 influenza virus obtained from infected mouse lungs by a combination of the methods of adsorption on and elution from chicken red cells and differential centrifugation. $\times 13,500$. 
THE JOURNAL OF EXPERIMENTAL MEDICINE VOL. 83

PLATE 1
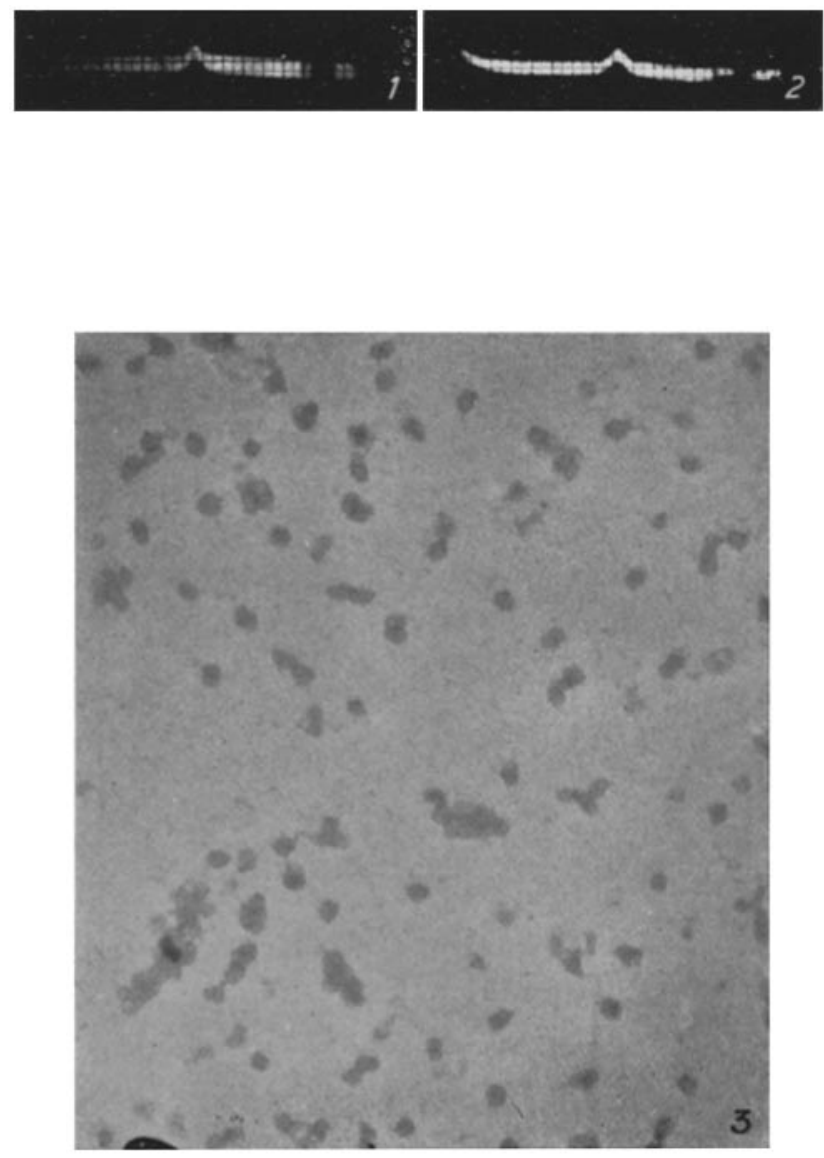

(Knight: Purified PR8 influenza virus) 